\title{
Territory and the governmentalisation of social reproduction: parliamentary enclosure and spatial rationalities in the transition from feudalism to capitalism
}

\author{
Alvaro Sevilla-Buitrago* \\ Universidad Politécnica de Madrid, Spain
}

\begin{abstract}

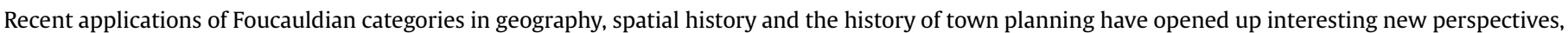

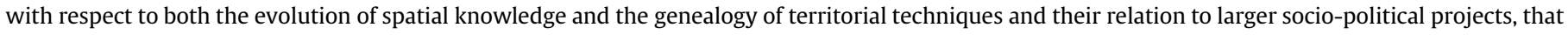

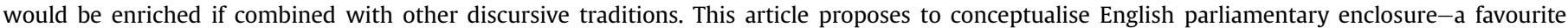

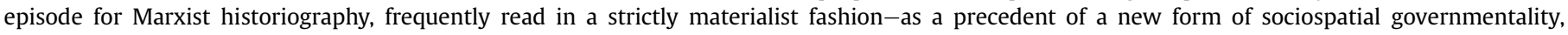

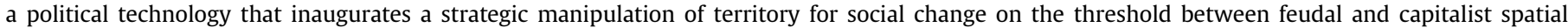

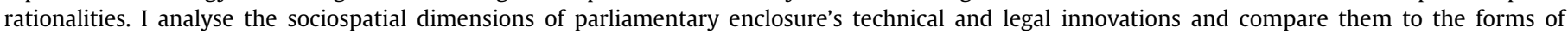

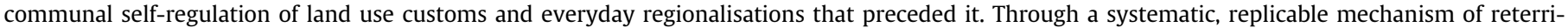

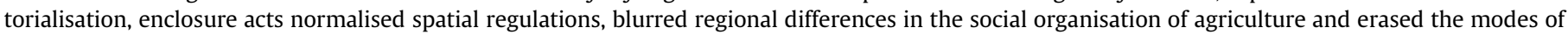

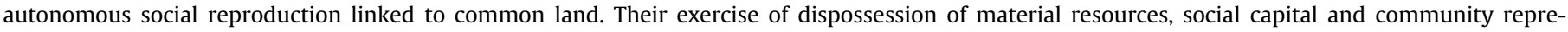
sentations is interpreted therefore as an inaugural logic that would pervade the emergent spatial rationality later known as planning.
\end{abstract}

(C) 2012 Elsevier Ltd. All rights reserved.

Keywords: Spatial governmentality; Territoriality; Parliamentary enclosure; Commons; Planning history; Michel Foucault

If this [common] land gets into the hands of a few great farmers, the consequence must be that the little farmers will be converted into a body of men who earn their subsistence by working for others, and who will be under a necessity of going to market for all they want. ${ }^{1}$

After one and a half centuries of life, the controversy about the social and economic consequences of enclosure and the disappearance of the commons not only remains open, but continues to grow. The long list of studies of enclosure by historians and historical geographers has now been recently extended by new materials and in recent years well-known geographers such as
David Harvey or Doreen Massey have added their contributions to a debate, whose duration is a fair indication of the role of enclosure in the dynamics of past and present social change. ${ }^{2}$ If historical geographers and economic and social historians have paid attention to its historical specificity as a key process in the transition from feudalism to capitalism, new disputes about the global commons and different modes of neo-liberal enclosure-from market-led agrarian reforms in the Third World to the commodification of genetic commons, from the battle of intellectual property rights to the gradual privatisation of urban public space-show the extent to which a logic of dispossession may be embedded in the evolutionary pattern of capitalism. ${ }^{3}$

\footnotetext{
* Departamento de Urbanística y Ordenación del Territorio, Escuela Técnica Superior de Arquitectura de Madrid, 4 Avda. Juan de Herrera, Madrid 28040, Spain.

E-mail address: alvaro.sevilla@upm.es

1 R. Price, Observations on Reversionary Payments, Vol. II, London, 7th Edition, 1812 [1771], 147.

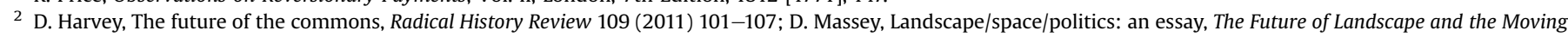

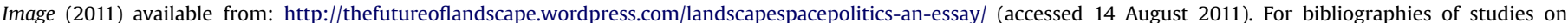

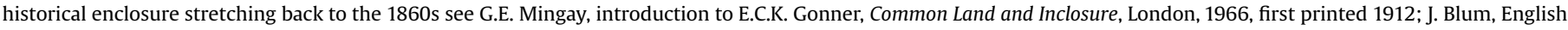

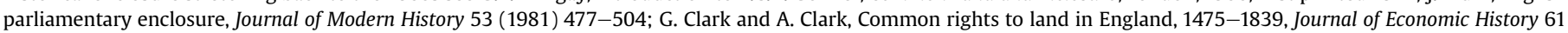

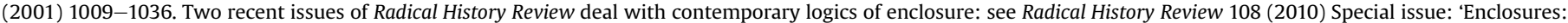
Fences, Walls, and Contested Spaces'; Radical History Review 109 (2011) Special issue: 'New Approaches to Enclosures'.

3 For recent developments on these aspects see, amongst others, A.H. Akram-Lodhi, Land, markets and neoliberal enclosure: an agrarian political economy perspective,

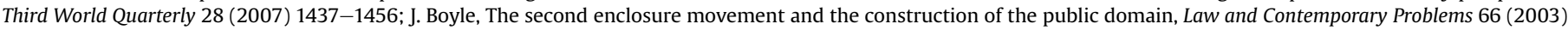

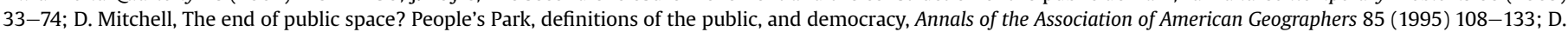

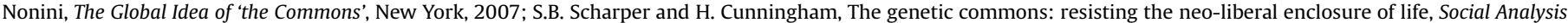
50 (2006) 195-202; A. Vasudevan, C. McFarlane and A. Jeffrey, Spaces of enclosure, Geoforum 39 (2008) 1641-1646.
} 
Although encouraged by these recent developments, my purpose in this paper is different: to return to English parliamentary enclosure in order to understand it as a precedent of a new form of sociospatial governmentality, a political technology that inaugurates a new strategic manipulation of territory for social change on the threshold between two historical spatial rationalities. Of course some of these concepts refer to Michel Foucault's work and, especially, to some of its recent applications within geography and planning history, particularly those of Stuart Elden and Margo Huxley. ${ }^{4}$ These developments are extremely interesting in themselves, opening up new, promising perspectives, both in regard to spatial knowledge and discourses and to the history of territorial techniques. However, some scholars have suggested that it is through the combination with other traditions in the social sciences that Foucault's readings on power would best contribute to understanding the relationship between these elements and more extensive social and political projects. ${ }^{5}$ For this reason, the present study emphasises the value of interpreting these technical and governmental devices in the context of processes of geopolitical change, the reshaping of class structure and the production of territory in England during the transition from feudalism to capitalism.

Through this approach I would like to raise some issues which I hope will contribute to recent debates over territory and planning, ${ }^{6}$ bringing together different traditions in the interpretation of sociospatial phenomena. Firstly, I highlight a series of temporal and spatial shifts: the most intense phases of parliamentary enclosure-between the second half of the seventeenth and the middle of the nineteenth century, a favourite moment in Marxist historiography-took place during a period which has received less attention in recent studies, but one which is essential for understanding the role of territorial techniques and legal innovation in contemporary processes of social transformation. Likewise, the nature of the territorial changes upon which enclosure was built oblige us to adopt a transversal view and to consider not only urban, national and international scales but also intermediate ones. For instance, the attention that Huxley focuses on the mature industrial city (and its alternatives) as the origin of a new form of spatial rationality ${ }^{7}$ risks reproducing the narrative schemes of conventional (reformist) planning history that she herself criticises, ${ }^{8}$ notwithstanding her use of Foucauldian categories. Studying the dynamics of parliamentary enclosure makes it possible to overcome these obstacles, since they require a more complex spatial interpretation-a change in the scale of analysis, attention to wider trends of territorial transformation and their reconfiguration in the relations between city and countryside. In turn, Elden insists that we refocus our attention on the history of 'territory' itself, counterbalancing the recent pre-eminence of the notion of 'territoriality'. That said, it is difficult to disregard this notion if, as he suggests, we want to understand territory not just as a word and a concept, but also as a practice. ${ }^{9}$ As I shall show, in order to grasp how previously-conceived territories are materialised in spatial form, it is necessary to consider the processes of deterritorialisation and reterritorialisation, spatial recodings and the agents which deploy them. Moreover, I do not consider it useful to enter into a detailed logical discussion to determine which moment-'territory' or 'territoriality'-takes precedence; it is more interesting to study how the dialectics of conceptions and practices operates in historical terms and to explore the ways in which both are connected in specific territorial formations. ${ }^{10}$

It was Foucault himself who warned that in order to understand discourses, one must understand their modes of social appropriation and how they are put into practice, and in order to comprehend techniques, it is necessary to analyse their effect on the subjects they affect. ${ }^{11}$ Such admonitions displace attention from an absolute conception of territory to a relative one, in which it appears as a means of social organisation and not as an end in itself-a shift that is consistent with that from territory to population as the ultimate objective of modern forms of governmentality, as elucidated in Foucault's courses at Collège de France. ${ }^{12}$ This interpretation is what moves me to take parliamentary enclosure as a window for understanding the threshold between rationalities of sociospatial government in the transition from feudalism to capitalism. There is an amalgam of old and new elements of territorial order in enclosure. In Elden's terms, the political-economic instance is developed by the legal and technical one, to achieve a new strategic form; however, this political strategy no longer exhausts itself in the control of territory, but uses it as a means for changing the conditions of social reproduction of the subaltern classes, thereby opening up the horizon for the coming of governmentality with its emphasis on the "conduct of conduct'. This article analyses the sociospatial dimension of technical and legal innovations incorporated by parliamentary enclosure compared to the forms of communal regulation that preceded it and characterises its exercise of dispossession of material resources, social capital and community representations as an antecedent which would be embedded in the emergent spatial rationality that was later expressed as planning. A perspective is thus opened up for an alternative genealogy of modern spatial planning techniques which would differ from the conventional one in its origins and content, in its objects and its horizon.

Before proceeding to the discussion of enclosure itself, it may be useful to specify the manner in which I am using the vocabulary of territory, territoriality, de/reterritorialisation and territorial techniques. Following the work of Claude Raffestin, ${ }^{13}$ I understand 'territory' as a coded space, a space structured by a series of codes or

\footnotetext{
${ }^{4}$ S. Elden, Governmentality, calculation, territory, Environment and Planning D: Society and Space 25 (2007) 562-580; S. Elden, Land, terrain, territory, Progress in Human Geography 34 (2010) 799-817; M. Huxley, Spatial rationalities: order, environment, evolution and government, Social and Cultural Geography 7 (2006) 771-787; M. Huxley, Geographies of governmentality, in: J.W. Crampton, S. Elden (Eds), Space, Knowledge and Power. Foucault and Geography, Aldershot, Hants, 2007, 185-204; M. Huxley, Problematizing planning: critical and effective genealogies, in: J. Hillier, P. Healey (Eds), The Ashgate Research Companion to Planning Theory: Conceptual Challenges for Spatial Planning, Farnham, 2010, 135-158.

${ }^{5}$ Particularly referring to the Foucault-Marx nexus, see B.J. MacDonald, Marx, Foucault, genealogy, Polity 34 (2002) 259-284; B. Jessop, From micro-powers to governmentality: Foucault's work on statehood, state formation, statecraft and state power, Political Geography 26 (2001) 34-40; S. Gunn, From hegemony to governmentality: changing conceptions of power in social history, Journal of Social History 39 (2006) 705-720; F. Driver, Power, space, and the body: a critical assessment of Foucault's, Discipline and Punish, Environment and Planning D: Society and Space 3 (1985) 425-446.

${ }^{6}$ See also M.C. Boyer, Dreaming the Rational City, the Myth of American City Planning, Cambridge, MA, 1997; L. Sandercock (Ed.) Making the Invisible Visible: A Multicultural Planning History, Berkeley, 1998.

${ }^{7}$ Huxley, Spatial rationalities (note 4).

8 Huxley, Problematizing planning (note 4).

${ }^{9}$ Elden, Land, terrain, territory (note 4), 812. See also the interesting debate between Stuart Elden and Marco Antonsich: M. Antonsich, Rethinking territory, Progress in Human Geography 35 (2011) 422-425; S. Elden, Response to Antonsich: the role of history, Progress in Human Geography 35 (2011) $426-429$.

${ }^{10}$ C. Raffestin, Territorialité: concept ou paradigme de la géographie sociale?, Geographica Helvetica 2 (1986) 91-96, 92.

${ }_{11}$ M. Foucault, The History of Sexuality, Vol. 1. An Introduction, New York, 1978, 92-102; M. Foucault, The subject and power, in: H. Dreyfus, P. Rabinow (Eds), Michel Foucault, Beyond Structuralism and Hermeneutics, Chicago, 1983, 208-226; M. Foucault, 'Society Must Be Defended'. Lectures at the Collège de France 1975-1976, New York, 2003, 27-28.

12 M. Foucault, Security, Territory, Population. Lectures at the Collège de France, 1977-78, New York, 2007; see also Elden, Governmentality, calculation, territory (note 4), 563.

13 For a general account of Raffestin's work see the recent theme issue in Environment and Planning D: Society and Space 30 (2012) 106-189.
} 
systems of social regulation, depending on certain objectives: 'Territory is generated from space, it is the result of the action of a syntagmatic actor ... By taking over ... a space, the actor "territorialises" [it]. ${ }^{14}$ This idea is certainly far removed from the one used by improvers and defenders of enclosure in their texts, in which the word 'territory' already appears in the modern conventional sense, either as a national territory or that of a landowner. Nonetheless, the meaning which Raffestin attaches to the term is closer to that reflected in actual territorial practices deployed during the eighteenth and nineteenth centuries. He considers territory as 'a production ... inscribed in a field of power', sustained by an assemblage of mediators-practices and knowledges, techniques and sciences-conditioned by the economic infrastructure and embodied in a series of codes, a regulatory system of meaning, access and exclusion. ${ }^{15}$ Territory 'is not an object' but 'a process in perpetual evolution'; it is not only a product, but also a means of production. It is not only the end of power-a pool of resources or assets with which social actors maintain an ultimate relationshipbut also the instrument used by these actors to control and subject other individuals-the point of triangulation by which a hegemonic group mediates its relation with subaltern classes. ${ }^{16}$ In any case, the specific implementation of these strategies depends on the social and historical conditions in which they appear and are put into practice, on the evolution of the techniques and knowledges that deploy them; in short, on the historical territorialities that mobilise these mechanisms in order to achieve a particular objective.

Raffestin defines territoriality as the system of relations that man (sic), as member of a collectivity, maintains with exteriority and alterity with the help of mediators in order to guarantee his autonomy'. ${ }^{17}$ This conception 'inverts the conventional order of geography, because the point of departure is no longer space, but the instruments and codes of actors that leave traces and signs on the territory'. ${ }^{18}$ Of course some Anglophone geographers will find points in common with the much better known notion proposed by Robert D. Sack. ${ }^{19}$ Nonetheless, although certain aspects of the latter approach are relevant for the subject matter of this article-such as its emphasis on the strategic uses of space and, in particular, attention to the role of dispossession in adapting the customs of pre-capitalist societies to markets ${ }^{20}$-Raffestin's approach is on balance more helpful, for a variety of reasons. These include the emphasis he places on techniques and the historical dialectic between knowledge and practices, which enables us to get a sense of how territory is produced; and also the fact that, for Sack, territory is merely an area of influence over which territoriality is exercised, whereas for Raffestin it is an assemblage with a much richer social significance and which, ultimately, is subject to a dynamic of permanent production/reproduction. ${ }^{21}$

As Raffestin himself suggests, 'all territories are included in a process of territorialisation-deterritorialisation-reterritorialisation, ${ }^{22}$-in other words, in a dynamic of coding of space, subsequent erosion (decoding) and replacement (recoding) of the systems of relationships that comprise them. Naturally, these codings include, amongst others, legal ones, and the parliamentary form of enclosure is an essential step in eliminating the more resistant codes of late-mediaeval territories-both in regions where the open-field system is more deeply rooted and in areas where wastes and common lands had greater importance-and their subsequent capitalist reterritorialisation. However, as I will show, its scope and strategic nature went far beyond its legal instrumentality.

\section{A global sense of enclosure}

Parliamentary enclosure is understood here as a new mode of reterritorialisation, a local process of production of territory and subjectification, deployed on a threshold between spatial rationalities induced by a global economic and geopolitical reconfiguration. Its main characteristic was the innovation and normalisation of, and through, techniques; its principal consequence, a systematic exercise of social dispossession at an individual and collective, material, institutional and emotional level. These techniques were inserted into a multi-layered strategy which must be analysed in depth, in order to understand this scheme in all its complexity. We need, in other words, a global sense of enclosure. The processes unleashed by parliamentary acts were related to an evolution in the ways of coding space-in the forms of territorialisation. They presented an explicit will to create a new territory that would give rise to a change in the scale of the traditional economic functions of the countryside and a change in degree in which territory and its resources would not be understood merely as an end in itself, but also as a means for governing the population. Although I shall dedicate the rest of the article to exploring this social plot, before doing so I will give a brief description of the global connections of these historical shifts.

Two principal objectives have traditionally been attributed to enclosure, both related to the agrarian revolution: firstly, the consolidation of land holdings, habitually divided and scattered throughout the parish into strips which prevented the use of modern farming techniques; and secondly, the releasing of land subject to collective crop regulation and the elimination of common rights, thereby allowing individual projects for improvement. ${ }^{23}$ Towards the eighteenth century, these objectives were more and more often expressed in terms of a national strategy. Enclosure, said John Laurence,

would be worth more to us, than the Mines of the Indies to the King of Spain ... a third of all the Kingdom is what we call Common-fields; and if so, then the raising the Rent of these, will vastly enrich the Kingdom. ${ }^{24}$

\footnotetext{
14 C. Raffestin, Pour une géographie du pouvoir, Paris, 1980, 138, 143, 129.

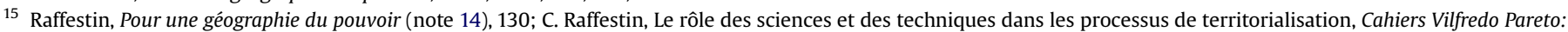
Revue européenne des sciences socials 108 (1997) 93-106, 100

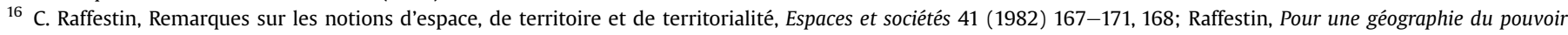
(note 14), 143-144.

17 C. Raffestin, Le territoire, la territorialité et la nuit, Actualités psychiatriques 2 (1988) 48-50.

18 Raffestin, Territorialité (note 10), 94.

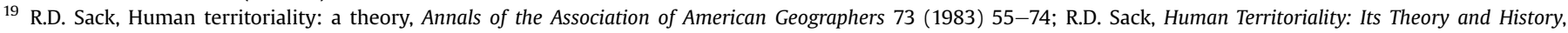
Cambridge, 1986.

20 S. Elden, Thinking territory politically, Political Geography 29 (2010) 238-241, 239; Sack, Human Territoriality (note 19), 78.

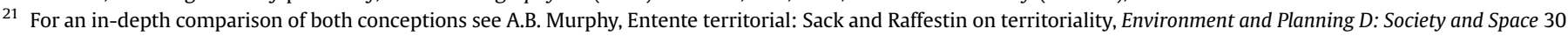
(2012) 159-172.

22 Raffestin, Le territoire, la territorialité et la nuit (note 17), 49.

23 Blum, English parliamentary enclosure (note 2), 481.

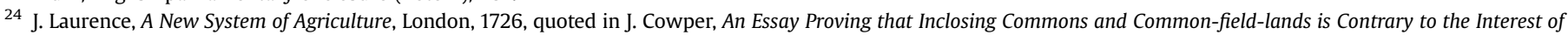
the Nation, London, 1732, 8-9.
} 
Similarly, Arthur Young would later argue that ' $t$ ]he advantages resulting from inclosures, are not to be looked upon as merely beneficial to the individual, they are of the most extensive national advantage'. ${ }^{25}$ But the horizon of enclosures was much wider and not always related to agrarian production. The land could be used for other activities-mining and the timber industry, or, in the nineteenth century, urban development-or to earn other economic profits. ${ }^{26}$ The increase in ownership was the fastest way to obtain wealth for landowners who retired from direct production to become rentiers and the reiterated cycles of property speculation fuelled these dynamics; enclosure was the key for penetrating territories whose institutional nature made it difficult to access ownership through market channels. Furthermore, the accumulation of land could constitute an objective for wider social reasons. Until the nineteenth century, land was 'the most permanent form of asset and the principal fount of influence and power ${ }^{27}$; the old landed gentry wished to increase its properties to obtain greater prestige and power on a local, regional or national level and new elites of urban merchants and manufacturers sought to raise their standing by buying rural properties and being incorporated into the social class that formally held hegemony. In this regard, it is interesting to note that a considerable part of enclosed land was used for a merely representative and recreation-related function, through setting up pleasure parks, ${ }^{28}$ or was left unused.

As we shall see in the ensuing analysis, apart from these 'direct' purposes-strictly political-economic and by no means newenclosure, particularly from the seventeenth century on, was used for a much more relevant strategy: that of transforming the modes of social reproduction and completing the process of proletarianisation of the rural subaltern classes, suppressing their relative independence with respect to wage labour and the satisfaction of basic needs in the market. ${ }^{29}$ Through this strategy, farmers were soon accompanied by merchant-manufacturers and merchantemployers seeking to widen the rural networks of domestic system and rid themselves of the guild regulations of the mediaeval city. ${ }^{30}$ John Arbuthnot bears explicit witness to this common objective:

[I]f by converting the little farmers into a body of men who must work for others more labour is produced, it is an advantage which the nation should wish for ... the produce being greater when their joint labours are employed on one farm, there will be a surplus for manufactures, and by this means manufactures, one of the mines of this nation, will increase, in proportion to the quantity of corn produced. ${ }^{31}$

In sum, in the complex, striated territories inherited from the era of feudal decline, enclosure-particularly parliamentary acts in sites where pre-existing codes were harsher and more resistant to the land markets-became the key for dismantling the precapitalist legal and sociospatial framework of the countryside, rendering it permeable to the market and to agents which were alien to, or not at ease with, the extraordinary diversity of local practices, customs and everyday regionalisations. Here was quite an array of problems in legal, economic and social terms, whose solution converged in suppressing common rights and the liberalisation of private exclusive control over land, changing from a common regime of property and production regulation to another in which each landowner could freely and permanently use land at will.

Nevertheless, in spite of its complexity, this process is only the visible tip of a much larger process in which the configuration of a new territorial hierarchy in England is at stake, as well as the nation's own position in the changing order of international forces. It is significant that the most intense period of parliamentary enclosure coincided with the decline of the second (Dutch) systemic cycle of accumulation and England's emergence to become a hegemonic international power in the formation of the capitalist world-system. ${ }^{32}$ Giovanni Arrighi argues that the development of the contradictions of each historical cycle of accumulation creates the necessary space for the emergence of alternative regimes in a dynamic of national and international turbulence, in which both the leading agencies and the aspiring ones submit their economic and social structures to profound and intense processes of change.

From the end of the seventeenth century England sought to extend its foreign trade, firstly by dominating the Baltic in order to sell to Holland and later by usurping the international supremacy of the latter. Cereal exports were one of the key elements in this endeavour and the state bounties and subsidies fostered national production for the overseas market to the point of converting England into the grain hegemon in Europe. ${ }^{33}$ This led to unprecedented pressure on the English countryside, on both land and the labour required to tend it. England lost this position in the second half of the eighteenth century, when the country went from being a net grain exporter to being a net importer due to an increase in domestic demand. ${ }^{34}$ Farmers attributed this change to an insufficient exploitation of national resources-communal limitations on the emerging capitalist agriculture, an abundance of wastes and other common lands, the impossibility of employing the poor due to the permanence of the subsistence economies permitted by the commons-making it impossible to respond to the increase in both domestic and international demand. For that reason, it was argued that traditional ways of life and production should submit to a strategy of intensive exploitation, regardless of the consequences: 'I do not mean to deny that some local disadvantages may occur, but these are too trifling and limited to merit attention, and still less to

\footnotetext{
25 A. Young, A Six Months Tour through the North of England, Vol. I, London, 228.

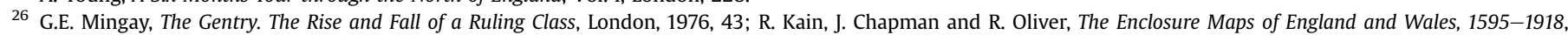
Cambridge, 2004, 7.

27 Mingay, The Gentry (note 26), 17.

28 R. Williams, The Country and the City, Oxford, 1973, 120-126.

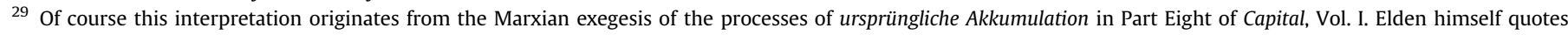

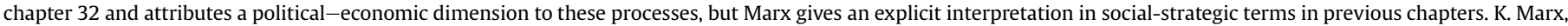
Capital: A Critique of Political Economy, Vol. I, Harmondsworth, 1976; Elden, Land, terrain, territory (note 4), 805.

30 M. Dobb, Studies in the Development of Capitalism, London, 1963.

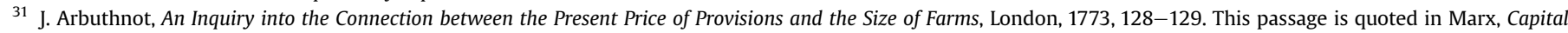
(note 29), 888-889.

32 G. Arrighi, The Long Twentieth Century. Money, Power, and the Origins of Our Times, London, 1994.

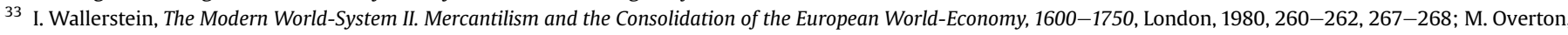
Agricultural Revolution in England: The Transformation of the Agrarian Economy 1500-1850, Cambridge, $1996,146$.

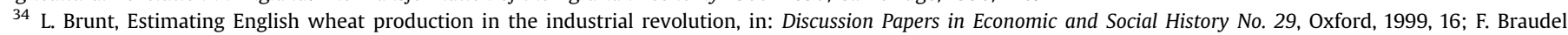
Civilization and Capitalism, 15th-18th Century: The Perspective of the World, Berkeley, 1992, 561.
} 
impede the progress of an improvement of the greatest national importance. ${ }^{35}$

It is interesting to observe that the calls for the general mobilisation of such resources in the pamphlets and reports written during that time were in many cases accompanied by an analysis of the global and regional connections that had to inform it. For instance, in his Inquiry, Arbuthnot devotes a whole chapter to studying England's geo-economic relationship with Holland, Poland, Prussia, Russia and America and claims a free trade policy in foreign and domestic markets to accompany the output increase. ${ }^{36}$ Such new forms of exchange and their articulations would be the channels used to transmit the dawning reterritorialisation. The upheavals in foreign markets and international policy led to a rescaling of the national market, strengthening and reorientating its formation, redefining the modes of production and distribution and the agents which regulated them.

We are witnessing a dynamic of de/recoding that can be traced both in territories of production and exchange. Of course this process was certainly not new. From the sixteenth century, a fierce battle had been waged between a new bloc of regional merchantmanufacturers and merchant-employers and the urban guilds and large monopolies of the City of London-between a shifting territoriality of circulation and a territoriality of borders and regulatory privileges-which filled the countryside with the spreading puttingout system networks. However, the proliferation of new economic forms became especially intense in the eighteenth century, as England consolidated its place in the international scene. The erosion and disappearance of late-mediaeval territories, the decline of guild cities and their forms of governing economic space, the degeneration of regulated markets and of the territorial networks of the towns that housed them, the eclipse of fairs, ${ }^{37}$ the crises afflicting old centres of craft production, the contradictions in corporation bylaws: all played their part. ${ }^{38}$ Simultaneously, we see the emergence of the territories of the new economy: the proliferation of free, pricefixing markets in all sectors, generating new locations, creating new accessibilities and regional differences ${ }^{39}$; the increasing prosperity of large farms of improved agriculture owned by the gentry and new mining and rural domestic system settlements; large mercantile cities consolidating their role as the command centres of the new national market and a colonial market in expansion.

The dramatic increase in the scale of trade in the economy from the seventeenth century was by no means homogeneous. As London gradually increased its area of influence to embrace areas further and further outside its limits, as the rules of exchange and production were normalised and the national market became consolidated, economic activity became more and more regionally specialised. ${ }^{40}$ Metropolitan and, subsequently, international demand reorganised the agricultural and industrial market, transforming a structure of relatively isolated regional cells into a differentiated network. The regions specialising in the production of commercial grain were very much affected, especially those in areas such as the fertile Midlands, where traditional social and agrarian codes continued to be deeply rooted. ${ }^{41}$

This field of forces provides the context within which we should understand the processes that turned the countryside into a strategic supporting territory for social change during this period. It became simultaneously the space of accumulation for old rentier landowners, a space for the settlement and recreation of new merchant capital, and also a space of exploitation free from urban regulations in which emerged a new army of dispossessed populations, totally dependent on the sale of their labour power. The desire to own land combined with that of depriving the subaltern classes of any way of accessing it, including common land. In these movements, there was a change from an exclusively economic practice of territory to another, more complex one that formulated a socio-political strategy with a much wider scope, materialised through new legal and technical tools. Here we cross a threshold between spatial rationalities: there is no substituting of one conception for another; as Foucault warns, these passages of governmental rationality must be understood in an additive, though non-linear, sense. ${ }^{42}$ Naturally, land never ceased to be a space of accumulation. Eighteenth- and early nineteenth-century commentaries on agrarian improvement-unerring indicators of contemporary practices-are fundamentally treatises of applied economics. However, more and more often, and in an increasingly systematic manner, they included schemes that denote explicitly class-based tactics and a national strategy, the will to fill the land with extra-economic codes, giving rise to denser and more complex territories. The conception of territory as a resource and reserve does not disappear, of course, but parallel codes are strengthened and new ones emerge which connect it to geo- and micropolitical processes that exceed the sphere of production; territory is still an end in itself, but also becomes a means.

What is more, these local conceptions of territory were not only determined globally in the social and economic sphere but also influenced by other forms of spatial understanding and in particular, by the geographical imaginations associated with colonial expansion. ${ }^{43}$ This, for example, is the mechanism that led John Sinclair, President of the Board of Agriculture, to declare the following at the beginning of the nineteenth century:

We have begun another campaign against the foreign enemies of the country ... Why should we not attempt a campaign also against our great domestic foe, I mean the hitherto unconquered sterility of so large a proportion of the surface of the kingdom? Let us try the effects of internal, as well as of foreign conquests. Let us not be satisfied with the liberation of Egypt, or the subjugation of Malta, but let us subdue Finchley Common; let us conquer Hounslow Heath; let us compel Epping Forest to submit to the yoke of improvement. ${ }^{44}$

\footnotetext{
35 J. Billingsley, General View of the Agriculture in the County of Somerset, London, 1794, 38.

36 Arbuthnot, An Inquiry into the Connection between the Present Price of Provisions and the Size of Farms (note 31), 113-119.

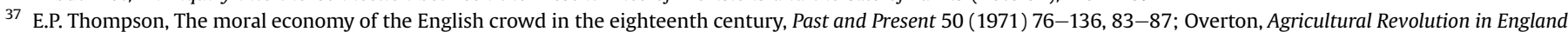
(note 33), 144; C. Hill, Reformation to Industrial Revolution: 1530-1780, Harmondsworth, 1969, 247.

38 Hill, Reformation to Industrial Revolution (note 37), 242-243.

39 R.A. Dodgshon, Society in Time and Space: A Geographical Perspective on Change, Cambridge, 1998, 142-143; Overton, Agricultural Revolution in England (note 33), 134.

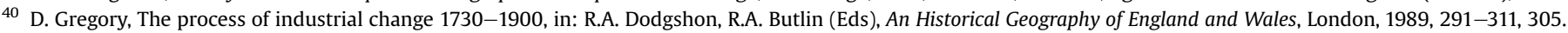

41 Overton, Agricultural Revolution in England (note 33), 48, 59.

42 Foucault, Security, Territory, Population (note 12), 10.

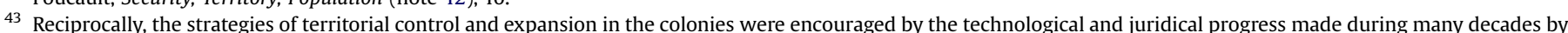

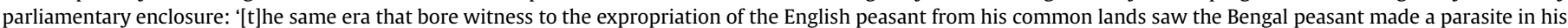

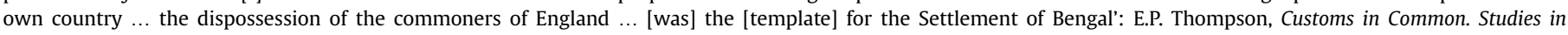

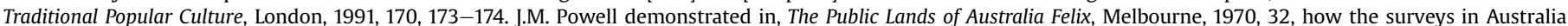
benefited from the techniques previously used by enclosure.

44 J. Sinclair, Memoirs of the Life and Works of the Late Right Honourable Sir John Sinclair, Vol. II, Edinburgh, $1837,111$.
} 
When the time comes to wage that battle on national territory, new conceptions of land materialise and are mingled with both new and old territorial practices, leading to a struggle of territorialities in which each social bloc tries to impose its own codes on space. In what follows I shall therefore examine those spatial codings in order to comprehend the decline of communal territorial formations and the emergence of new territories of dispossession.

\section{Open fields and common land}

I will first consider the system of sociospatial codes against which enclosure would henceforth operate. It should be emphasised that the diagrammatic nature of the following descriptions betrays the extraordinary diversity in ownership patterns, modes of agrarian production and forms of life of the different regions, which is characteristic of mediaeval social dispersion. ${ }^{45}$ This warning is necessary not only in order to remain true to the purpose of this study, but also to enable a fuller understanding of the operation of a logic of parliamentary enclosure which attempted to homogenise and normalise territory in a single pattern, starting from that complex geographical constellation of local practices and customs.

As regards the property regime under feudalism, broadly speaking, we can identify a typical structure for the manor. Besides the lord's house and the village, life revolved around three types of land: (a) demesne lands or terræ dominicales, reserved for the lord's own use and for the materialisation of the serfs' corvée, part of which was used as lands held by some of them in copyhold; (b) tenemental lands or terræ tenementales, given by the lord of the manor in freehold; and (c) various types of waste land ${ }^{46}$ (woods, moors, marshes, roads...). This model began to change with the feudal crisis, leading to a transition to protocapitalist forms of ownership. Direct labour-services were replaced with monetary rents, modern accounting and farming methods were developed and, with the gradual disappearance of serfdom, a new social structure was born. The gentry, a social bloc formed by the most wealthy stratum of the yeomanry, important traders who had moved to the country and elements of the old aristocracy who successfully adapted to the new order and whose common denominator was an active, strategic territoriality, ${ }^{47}$ concentrated land and became the hegemonic class from the seventeenth century until the early nineteenth century. Despite these changes, certain practices survived the impact of these social upheavals. This is the case with many common rights which were exercised over the different types of land and transferred through the sale or legacy, since they were bound to the possession of the land. ${ }^{48}$

A specific regime for the social use of land, a field system, was superimposed on the property scheme described above, with only partially-coinciding limits. During the initial processes of transition from feudal to allodial property, the organisation of the land underwent certain transformations but maintained its basic structure through a common farming regulation, the open-field or common-field system. ${ }^{49}$ Some areas of south-east, west and northwest England were never open or were enclosed early. In contrast, in the richest and most densely-populated regions-the Midlands, parts of Southern England and, with its own particular features, East Anglia-crops and the open-field system predominated. ${ }^{50}$

The open-field system had three elements, each one with its own regulation of common right. ${ }^{51}$ In the first place, were the arable fields, with their characteristic pattern of long, narrow strips and a crop regime agreed collectively, often since the High Middle Ages. ${ }^{52}$ Each farmer held rights over one or several strips of land scattered all over the parish, sometimes relocated every year; the land could be cultivated individually but they had to assume the local regulations regarding crop rotation, plough regime, and so on. After harvesting, these fields were used as common pastureland for up to 8 months, for which reason they were also known as 'commonable lands'.

The rest of the land was common land and, in turn, divided into two types: common meadows, distributed annually in a similar way to the arable fields, among local landowners and tenants for use as pastureland or individual crops and also subject to collective usufruct after harvesting, and different forms of common pastures and waste land, permanently available for common usufruct under a specific regulatory framework.

In the above-mentioned regions, this tripartite system was dominant-around three-fifths of all land used for crops, or 53\% of the total surface area of England around 1600-and usually occupied the entire parish for centuries, which has been interpreted as proof of its efficacy. ${ }^{53}$ The proportion of common land was variable. From 1235 on, the Statute of Merton allowed the lords to take over part of it if the remainder was sufficient to satisfy the commoners' needs. However, in most regions these common lands were independent entities reaching 8000-10,000 acres in parishes with less than 100 inhabitants, often much larger than the arable fields or, in

\footnotetext{
${ }^{45}$ G. Homans, The explanation of English regional differences, Past and Present 42 (1969) 18-34; S. Rippon, Historic Landscape Analysis: Deciphering the Countryside, York, 2004, 1; T. Williamson, Shaping Medieval Landscapes. Settlement, Society, Environment, Oxford, 2003, 5-7.

${ }_{46}$ The property regime of common land was the subject of lengthy disputes. During the height of the feudal period, lawyers considered it to be a domain of the lord, the usufruct of which was assigned to the serfs on a paternalistic basis. 'The law pretended that ... the commons were granted by benevolent Saxon or Norman landowners, so that uses were less of right than by grace': Thompson, Customs in Common (note 43), 160-161. Following the decline of the feudal system, this version was challenged by popular narratives: according to the myth of the Norman Yoke, William the Conqueror would have taken the lands farmed collectively from the common Anglo-Saxon hamlets in order to donate them to his armies in 1066. Twentieth century historians have confirmed that common rights were 'the oldest element' in the common-field system, 'the residue of more extensive rights ... enjoyed from time immemorial, which the Anglo-Saxon and later Norman kings and manorial lords curtailed': J. Thirsk, The common fields, Past and Present 29 (1964) 3-25, 4.

47 P. Coss, The Origins of the English Gentry, Cambridge, 2003.

48 Blum, English parliamentary enclosure (note 2), 478.

49 David Hall found signs of Saxon origin for this system in England, resulting from a thorough reorganisation of the field patterns during the period 650-850; see W Matzat, Long strip field layouts and their later subdivisions: a comparison of English and German cases, Geografiska Annaler: Series B, Human Geography 70 (1988) 133-147, 136, 141; Homans, The explanation of English regional differences (note 45), 30-31; Williamson, Shaping Medieval Landscapes (note 45), 12.

50 A.R.H. Baker and R.A. Butlin, Studies of Field Systems in the British Isles, London, 1973; Homans, The explanation of English regional differences (note 45), 22; J.R. Wordie, The chronology of English enclosure, 1500-1914, The Economic History Review 36 (1983) 483-505, 490-491.

51 J. Thirsk, The common fields (note 46), 3; J.Z. Titow, Medieval England and the open-field system, Past and Present 32 (1965) 86-102, 86-87; Clark and Clark, Common rights to land in England, 1475-1839 (note 2), 1009; L. Shaw-Taylor, Parliamentary enclosure and the emergence of an English agricultural proletariat, Journal of Economic History 61 (2001) 640-662, 642.

${ }^{52}$ For different hypotheses about the origin of these patterns see G. Slater, The inclosure of common fields considered geographically, Geographical Journal 29 (1907) $35-55$, 39; R.A. Dodgshon, The landholding foundations of the open-field system, Past and Present 67 (1975) 3-29; S.J. Rippon, R.M. Fyfe and A.G. Brown, Beyond villages and open fields: the origins and development of a historic landscape characterised by dispersed settlement in south-west England, Medieval Archeology 50 (2006) 31-70, 66; C.J. Dahlman, The Open Field System: A Property Right Analysis of an Economic Institution, Cambridge, 1980. Most academics agree on the attribution of communal elements of economic democracy to those origins, as well as the organised and regulated nature thereof.

53 Wordie, The chronology of English enclosure, 1500-1914 (note 50), 491; Dahlman, The Open Field System (note 52).
} 
some cases, covering an entire parish. ${ }^{54}$ At the beginning of the seventeenth century, more than half the land was common in the 12 Midlands counties which later had the highest fraction of land enclosed by Parliament; in Middlesex, for instance, the amount of common land was equivalent to $85 \%$ of the open arable fields and to $74 \%$ of all the land still cultivated in $1798 .{ }^{55}$ On the whole, the proportion of waste land was around one-quarter of the total surface area of England and Wales at the end of the seventeenth century. ${ }^{56}$

\section{Common right and autonomous forms of social reproduction and self-government}

Heterogeneity was also a feature of legal forms and everyday uses associated with common and commonable lands. As lex loci resulting from local custom, their scope was linked to the historical evolution of relations of property and production in each parish, to the nature of its soils and main activities. The custom did not present a static, normalised spatiality, but one connected by all manner of social practices in a permanent process of transformation; the result was a complex, striated topology, woven on a basis of subtle superimpositions and crossed by variegated territorialities, which were often contradictory. ${ }^{57}$ The custom was not a space of spontaneous consensus, but one of permanent friction and dispute which required a dynamic approach to regulation.

With respect to the common right, the most frequent forms included rights of pasturage, gleaning and the gathering of fuel and other materials, but its scope was varied: pasturage could range from the livestock registered in the name of the owners of the arable land to any animal belonging to any resident of the parish; gathering of materials could include just firewood and peat, or be extended to include felling trees for building cottages, etc. As well as these basic forms, there were often also hunting and fishing rights. ${ }^{58}$ Following the implementation of the Poor Laws of 1597-8 and 1601-drafted, in part, as a response to conflicts derived from enclosure, including vagrancy, depopulation, dearth and riots ${ }^{59}$ the rights were extended to a wider segment of the population (including non-owners) and new uses were added for land, including the building of cottages for the poor. ${ }^{60}$ Even so, access was practically always limited to members of the local community; for the purpose of regulation and until the alteration of the traditional order and the re-scaling of class struggle due to enclosure and other territorial dynamics, the parish normally functioned as a closed, exclusive universe. ${ }^{61}$
One of the most interesting aspects of the open-field system is its character as a sociospatial and economic institution. These forms of law responded to a self-managed collective system and materialised through a detailed land use regulation; they 'were not the result of ... haphazard developments, but ... the outcome of conscious planning, both in terms of their organisation, and in their physical layout'. ${ }^{62}$ Twice a year, the local landholders or cottagers-or sometimes, the whole community-agreed and drafted the field orders, documents which regulated the communal land use regime for all the families. ${ }^{63}$ The planning was extremely careful. 'The hamlet was the unit of cultivation, not the farm. The farmer did not farm as he chose, but according to the method prescribed for him, by common agreement guided by custom,64; the parish considered its own needs and gave itself a series of collective regulations that set the boundaries of the land and its uses, crop rotation and the types of cultivations to be sown, actions for improvement and the persons assigned to carry them out, the dates and terms for completing the different tasks and the exercise of common rights, pasturage turns in common land and paid shepherds responsible for them, fines imposed on persons infringing the regulations, etc. In short, here was a spatial coding, an extremely advanced everyday territorialisation-in some aspects even more so than their urban equivalents-designed collectively with the direct or indirect participation of all the inhabitants. At the end of the meetings, they would drink to celebrate the decisions taken, the resolution was announced through the hamlet and a copy of the order was nailed to the church door for everyone to see. ${ }^{65}$

The second aspect to be highlighted in relation to the common right is a purely material one, with significant repercussions for contemporary modes of social reproduction. The common rights and their usufruct would rarely have allowed families to be selfsufficient, but provided informal income which, for certain segments of the rural population-small freeholders, craftsmen and above all, agricultural day-labourers and domestic workers involved in the putting-out system-were converted into a fundamental element of household economies in their attempts to resist exclusive dependence on wage labour and to ensure the satisfaction of basic needs in the market. ${ }^{66}$ Gleaning could thus earn a woman sufficient grain to make bread for 1 year or an equivalent amount to a salary earned by an adult male in 7 weeks; gathering fuel could be equivalent to another 6 weeks of salary and other benefits associated with the commons could bring annual earnings similar to those obtained by employed women. ${ }^{67}$ The most valuable usufruct came from animal products acquired through pasturage: the

\footnotetext{
54 Kain, Chapman and Oliver, The Enclosure Maps of England and Wales, 1595-1918 (note 26), 5.

55 Clark and Clark, Common rights to land in England, 1475-1839 (note 2), 1028; A.D. Hall, English Farming Past and Present, London, $1936,191$.

56 Blum, English parliamentary enclosure (note 2), 479.

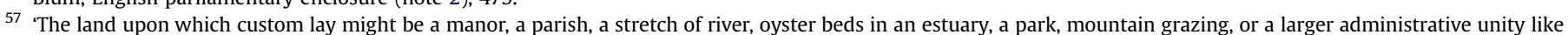
a forest': Thompson, Customs in Common (note 43), 98.

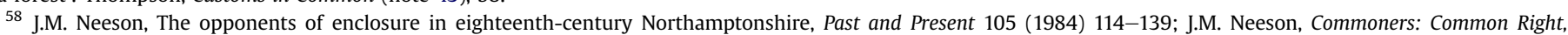
Enclosure and Social Change in England, 1700-1820, Cambridge, 1993.

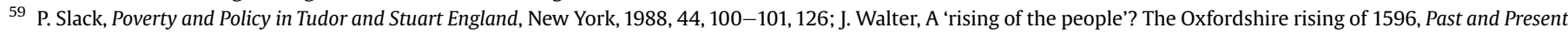
107 (1985) 90-143.

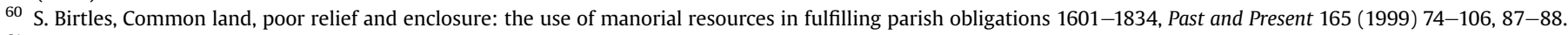

61 Dahlman, The Open Field System (note 52), 101.

62 A. Nash, The medieval fields of Strettington, West Sussex, and the evolution of land division, Geografiska Annaler: Series B, Human Geography 64 (1982) 41-49, 41.

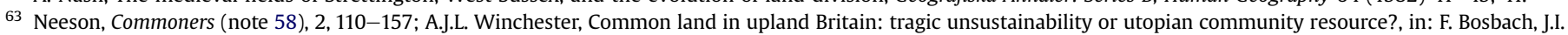
Engels, F. Watson (Eds), Umwelt und Geschichte in Deutschland und Grossbritannien, Munich, 2006, 61-76.

64 Slater, The inclosure of common fields considered geographically (note 52), 36.

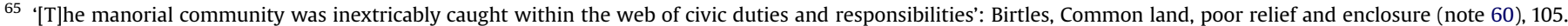

66 Neeson, Commoners (note 58), 158-184.

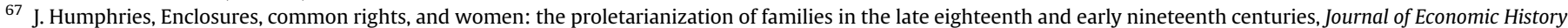

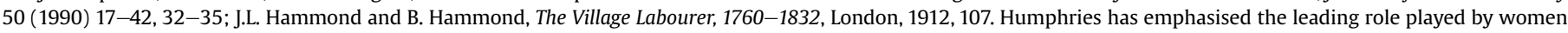
in communal economies, suggesting that the disappearance of the commons contributed to their reclusion at home.
} 
earnings from owning a cow were equivalent to between onefourth and the total annual earnings of an adult male, added to which were those arising from owning pigs, geese, sheep and so forth. ${ }^{68}$

In sum, the benefits of the commons allowed the less fortunate to resist processes of proletarianisation and exclusive dependence on wage labour pursued by the emerging order, thanks to local, selfgoverned regulatory-spatial planning which made it possible to maintain a partly autonomous mode of social reproduction outside the market. ${ }^{69}$ The experience of such groups was shaped by the frictions between two fundamentally opposing conceptions of labour and the use of time, everyday life and the very forms of social and economic organisation. The gentry, particularly after the Civil Wars, accumulated land and fought to suppress the old openfield system. Determined to subject the fields to improvement, they increasingly adopted a capitalist mentality in operating their farms and demanded 'a new and extensive source of labour of the most productive kind ${ }^{70}$ for setting up their projects; an objective from which merchant-manufacturers and merchant-employers also benefited, by transferring textile manufacturing to the countryside to evade guild regulation. ${ }^{71}$ However, what they found was not a disciplined, willing reserve army of labour power, but-in their opinion-a bunch of lazy good-for-nothings to whom communal usufruct had given 'an idea of visionary independence which [rendered] them unfit for the duties of their station'. ${ }^{72}$

Of course this was just another expression of the historic failure to try and "inforce Idle Persons to work ${ }^{73}$ attempted by the Elizabethan Poor Law. ${ }^{74}$ If direct policies had failed, future hegemonic blocs would try to instil a system of triangulation in social relations, mobilising their territorial power in order to achieve their goal. The idea that common land and the benefits they offered were responsible for the persistence of modes of social reproduction other than the wage-market nexus had existed at least from the mid sixteenth century, but it became dominant in the eighteenth century. Commons, it was said, were 'a hindrance to Industry ... Nurseries of Idleness and Insolence', 'seminaries of mischief' which 'induced many to rely on the cows and sheep they could keep, to exempt them from labour'. ${ }^{75}$ Literature written during that period contains eloquent proof of this conflict:

The benefit which they are supposed to reap from commons ... I know to be merely nominal; ... what is worse ... it is an essential injury to them, by being made a plea for their idleness; for ... if you offer them work, they will tell you, that they must go to look up their sheep, cut furzes, get their cow out of the pound, or, perhaps, say they must take their horse to be shod, that he may carry them to a horse-race or cricketmatch. $^{76}$
Moral effects of an injurious tendency accrue to the cottager, from a reliance on the imaginary benefits of stocking a common. The possession of a cow or two with a hog, and a few geese, naturally exalts the peasant in his own conception, above his brethren in the same rank of society. It inspires some degree of confidence in a property, inadequate to his support. In sauntering after his cattle, he acquires a habit of indolence. Quarter, half, and occasionally whole days are imperceptibly lost. Day labour becomes disgusting; the aversion increases by indulgence; and at length the sale of a half-fed calf, or hog, furnishes the means of adding intemperance to idleness. ${ }^{77}$

\section{Enclosure acts: proceedings, patterns and repercussions}

In order to establish the new order, as the gentry was well aware, it was necessary to eliminate this foreign element, this resistant code of pre-capitalist social territories, common rights and lands. This would

be the means of producing a number of additional useful hands for agricultural employment, by gradually cutting up and annihilating that nest and conservatory of sloth, idleness and misery, which is uniformly to be witnessed in the vicinity of all commons, waste lands and forests... [I]n viewing [these people's] habitations, the appearance of themselves and families, to say nothing of their morals, in comparison with what is daily to be witnessed in the family and appearance of the steady day-labourer ... is quite sufficient to justify the Surveyor in an earnest wish, that ... he yet may live to see the day when every species of intercommonable and forest rights may ... be extinguished. ${ }^{78}$

During the eighteenth century, farmers increasingly connected the virtues of enclosure with the submission of labourers: 'Inclosure is the greatest Encouragement to good Husbandry, and a Remedy for Beggary, the Poor being employed by the continual Labour that is bestowed thereon' ${ }^{79}$

When the commons are enclosed the labourers will work every day in the year, their children will be put out to labour early', and 'that subordination of the lower ranks of society which in the present times is so much wanted, would be thereby considerably secured'. ${ }^{80}$

This great transformation was to take the form of a general mobilisation. The government had to 'encourage as far as possible by legislative regulations, the laying into severalty, and enclosing where necessary, all common-field, common meadows, and

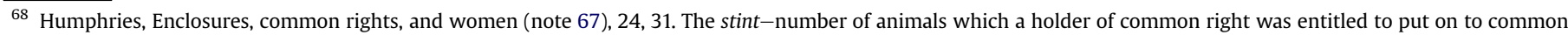

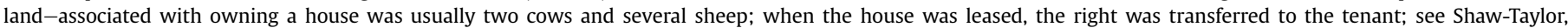
Parliamentary enclosure and the emergence of an English agricultural proletariat (note 51), 642-645.

69 Marx, Capital (note 29), 887-889.

70 Billingsley, General View of the Agriculture in the County of Somerset (note 35), 37.

71 Dobb, Studies in the Development of Capitalism (note 30).

72 J. Sinclair, The Code of Agriculture, Hartford, 1818, 45.

73 M. Hale, A Discourse Touching Provision for the Poor, London, 1683, 20.

74 Slack, Poverty and Policy in Tudor and Stuart England (note 59), 128; S. Hindle, On the Parish? The Micro-politics of Poor Relief in Rural England c.1550-1750, Oxford, 2004, 9, 171.

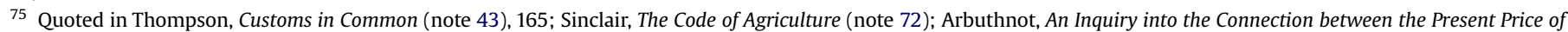
Provisions and the Size of Farms (note 31), 83-84.

76 Arbuthnot, An Inquiry into the Connection between the Present Price of Provisions and the Size of Farms (note 31), 81.

77 Billingsley, General View of the Agriculture in the County of Somerset (note 35), 36-37.

78 C. Vancouver, General View of the Agriculture of Hampshire, London, 1810, 496.

79 Laurence, A New System of Agriculture (note 24), 15.

80 Quoted from the Report on Shropshire of 1794 in Hammond and Hammond, The Village Labourer, 1760-1832 (note 67), 38.
} 
commons ... all the wastes, chases, and forests'; 'the men [would not be] lost, but ... with the ground, better employed'. ${ }^{81}$ It is not unusual to find proposals regarding the new location of those displaced by enclosure or even the creation of new, properly regulated settlements close to the workplace.

Consequently, the possibility of a new territorial governmentality began to take shape, one which hinted at the possibility of an integral management of rural sociospatial formations. And yet it should not be forgotten that the geographical scope of even the most visionary schemes was limited. The incorporation of these strategies into the regular practices of the state was slow, discrete, spatially uneven and protracted: more than one century passed between the first testimonies quoted above and the implementation of General Acts. ${ }^{82}$ As Patrick Joyce indicates in his study of nineteenth-century urban governmentalities, changes were at first proposed and put into practice outside public administration and only later gradually incorporated into the state apparatus. ${ }^{83}$ Despite the increasingly systematic nature of the rural dispossession, the history of enclosure was by no means straightforward.

As already indicated, the process of regulated enclosure dates from the thirteenth century, but after the Civil Wars there was a new phase in its development. Until then, its scope had been limited, both geographically and regarding the proportion of enclosed land. The usual practice during this period was piecemeal enclosure or collectively arranged enclosures by agreement, which restricted its size: it was frequent for the agreement to be partial and only a portion of the parish was enclosed. ${ }^{84}$ Strongly conditioned by the pre-existing property structure ${ }^{85}$ the activities were usually limited to redistributing the arable fields, leaving the common land and the rights associated with it intact, or conserving a surface area sufficient to satisfy the needs of the commoners. Thus, apparently until the seventeenth century, processes of enclosure remained subject to a local moral economy, although it appears clear that in this situation, the good intentions of the landowners were less important than the fear of their neighbours' reprisals and the anti-enclosure laws promoted by the Tudors due to fears of social disorder, popular riots and the depopulation of the countryside. ${ }^{86}$

However, from the seventeenth century, a new mode of enclosure developed, in which Parliament concentrated the process through legislation which affected the entire parish, including the common land. ${ }^{87}$ As Marx indicated, until then 'the process was carried on by means of individual acts of violence'; in the new scenario the law itself ... becomes the instrument by which the people's land is stolen'. ${ }^{88}$ The systematic potential of this new mechanism was soon evident. At the beginning of the seventeenth century, $47 \%$ of the surface area of England was subject to a regime of exclusive property, either because it had never been common or as a result of previous enclosure. Between the first acts at the beginning of the seventeenth century and 1914, when parliamentary enclosure was abandoned, another $48.4 \%$ was closed, leaving scarcely $4.6 \%$ of open fields. ${ }^{89}$ Most enclosures-37\% of the total surface area-were concentrated in the seventeenth and eighteenth centuries, giving rise to a practice of dispossession that operated in and through territory and produced a new reserve army of labour, totally dependent on wages and the market for its social reproduction.

Parliamentary enclosure had a geographically uneven development. ${ }^{90}$ It was especially intense in the central regions-strongly linked to the open-field system and concentrated on commercial grain-and throughout England in areas where there were difficulties in establishing enclosure using other methods. ${ }^{91}$ The nature of previous field systems, forms of settlement, property structure, customs of tenure and inheritance, proportion of common land, social organisation and types of farming had favoured early nonparliamentary enclosure in counties such as Essex, central Suffolk, Hertfordshire, Cornwall, Devon, Somerset, Herefordshire, Shropshire or Worcestershire. ${ }^{92}$ In contrast, in the central Midlands and other regions enclosure required the force and systematic approach of the legal form. By the beginning of the seventeenth century, 53\% of the land was farmed under the open-field system in the twelve counties which subsequently had the highest proportion of land enclosed by Parliament: Bedfordshire, Berkshire, Buckinghamshire, Cambridgeshire, Huntingdonshire, Leicestershire, Lincolnshire, Northamptonshire, Nottinghamshire, Oxfordshire, Rutland and the East Riding of Yorkshire; in all, just under a quarter of the farmland area of England. ${ }^{93}$ In the South Midlands between $77 \%$ and $82 \%$ of the land was subject to a communal regime in 1575 , and $55 \%$ in 1750 , after which date $96 \%$ of enclosure was by parliamentary act. ${ }^{94}$ All in all, 'Parliamentary enclosure affected about $25 \%$ of the land area of England'. 95

However, despite its spatial unevenness, the trends unleashed by the parliamentary form were clear: enclosure acts were the key to 'decoding' the most resistant territories ${ }^{96}$; once they appeared in a specific region, legislation prevailed over other methods, due to their greater efficiency. Enclosure by agreement was gradually abandoned, particularly from the eighteenth century on. Enclosure

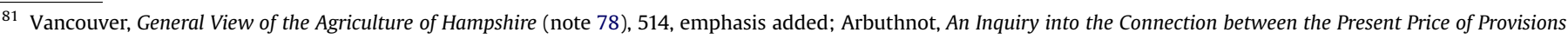
and the Size of Farms (note 31), 136.

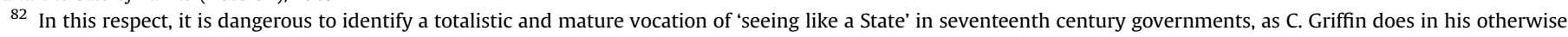
interesting, More-than-human histories and the failure of grand state schemes: sylviculture in the New Forest, England, Cultural Geographies 17 (2010) $451-472$.

83 P. Joyce, The Rule of Freedom. Liberalism and the Modern City, London, 2003, 24.

84 Blum, English parliamentary enclosure (note 2), 478.

85 Homans, The explanation of English regional differences (note 45), 27-28.

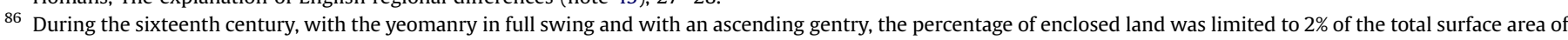
England. See Wordie, The chronology of English enclosure, 1500-1914 (note 50), 494.

87 M. Turner, English Parliamentary Enclosure: Its Historical Geography and Economic History, Folkestone, 1980.

88 Marx, Capital (note 29), 885.

89 Wordie, The chronology of English enclosure, 1500-1914 (note 50), 485-486, 502.

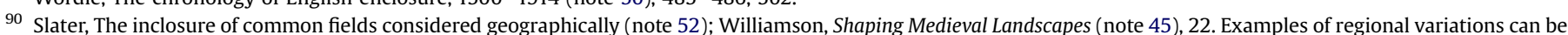

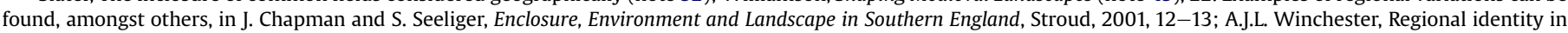
the Lake Counties: land tenure and the Cumbrian landscape, Northern History XLII (2005) 29-48.

91 Williamson, Shaping Medieval Landscapes (note 45), 2-5.

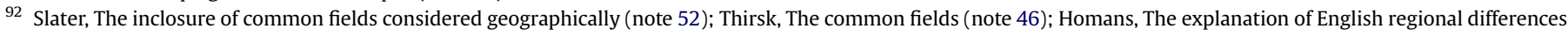
(note 45).

93 Clark and Clark, Common rights to land in England, 1475-1839 (note 2), 1029-1030.

94 R. Allen, Enclosure and the Yeoman. The Agricultural Development of the South Midlands 1450-1850, Oxford, 1992.

95 J. Chapman, Field systems and enclosure, in: R. Kitchin, N. Thrift (Eds), International Encyclopedia of Human Geography, Vol. IV, Amsterdam and Oxford, $112-118,117$.

96 Chapman and Seeliger, Enclosure, Environment and Landscape in Southern England (note 90), 19.
} 
Acts were much more flexible and reliable, and also ensured the distribution of common land among local owners. The subsequent legal and managerial homogenisation of the different regional socioagrarian systems and subsystems into a single model of exclusive dominium would pave the way for the full consolidation and penetration of markets and their new agents. In short, parliamentary enclosure normalised territorial regulations, blurring or doing away with local customs and practices, with regional differences in the methods of social organisation and management of agriculture and the modes of reproduction linked to it, through a systematic, replicable, regulated mechanism of reterritorialisation ${ }^{97}$-a trend which would be even more consolidated with the approval of the General Inclosure Acts during the nineteenth century.

The protocol for drafting and processing acts was sophisticated and radically opposed to communal self-governing planning practices and the social institutions associated with them. It comprised three phases. In the first, the owners of at least three-quarterslater $80 \%$-of the private land of the parish were required to agree to the enclosure and to ask Parliament to pass a bill regulating the process. From 1774 this request had to be posted publicly on the church door for three consecutive Sundays. The second phase started with the drafting of a Bill of Enclosure and its reading in the House of Commons, following which a Parliamentary Commission was formed to study the initiative and hear the allegations, a participative process that replaced the traditional assembly debate in the parish. After the Commission's report, the Bill was again read and passed to the House of Lords, where it received royal approval and became an Enclosure Act. ${ }^{98}$

In practice, this process was often fraught with irregularities. The majority owner often prepared the plan without the knowledge of his neighbours and presented it without alternatives before submitting it to the Parliament for it to be signed. The calculation of ownership was often manipulated and until 1801, the interested parties could be members of the commission evaluating the initiative. ${ }^{99}$ In 1880 , one century after establishing the requirement for the process to be made public, a motion was submitted to the Parliament for the purpose of establishing measures to make it effective in the counties-the majority-in which it had not yet taken effect. The greatest blow to popular participation was the transfer of the headquarters of the debate from the local assembly to the Parliament and its codification based on processes far removed from the customs of the villagers. As the Hammonds ironically indicated, any farm labourer could oppose an enclosure initiative: all they had to do was learn how to read, hire a lawyer, go to London for a few weeks and face the pressure of the most powerful villagers. ${ }^{100}$

During the third phase, the enclosure management process was implemented by the preparation of an Award which mapped the new apportionment of land, distributed the benefits and charges and established the terms for executing the work and the obligations of the owners. The surveyors arrived at the parish with their equipment and set up there. 'The life and business of the village are now in suspense, and the commissioners are often authorised to prescribe the course of husbandry during the transition'. ${ }^{101}$ The preparation of the map developed a new logic of calculation, far removed from local custom, which took its time. After identifying the interested parties, the new parcelling was defined, as well as the path of the new roads, the correction of water courses and the drainage and channelling systems and the instructions for enclosing the properties. The execution of the project was often a source of conflict. Soon, the reluctance of small landowners to build the enclosures due to the cost of the operation and the reprisals of their dispossessed neighbours made it necessary to establish deadlines and fines for those who failed to comply. The process was often centralised, creating squads of day-labourers entrusted with carrying out the work under the supervision of the surveyors, which was then charged to the owners.

In short, for small landowners, enclosure was in one way or another compulsory and they usually had to make fatal disbursements; many sold their lands during the process or did so shortly afterwards, due to not being able to repay the loans they had taken out to undertake the transformations. ${ }^{102}$ Between the middle of the seventeenth and the end of the eighteenth century, their numbers had fallen by more than $60 \%$ in some counties and the amount of land they owned was reduced by more than $80 \% ;{ }^{103}$ as one observer had warned in 1780, 'strip the small farms of the benefit of the commons, and they are all at one stroke levelled to the ground. ${ }^{104}$ For the tenants the consequences were also devastating: it was usual for rents to be doubled and tripled after enclosure within scarcely one decade. ${ }^{105}$ In a very harsh and violent process of working-class formation, the dispossessed yeomen joined the lines of day-labourers, along with those whose only way to access land was exclusively through the communal regime; the repercussions of enclosure on these were even more severe, ${ }^{106}$ and their condition changed from being a semi-proletarian group, partially independent from wage labour and the market, to the status of full proletarians.

\section{Conclusions}

The contemporary debate on the social model generated by mass enclosure leaves no room for doubt. Regardless of their stance, all the contributors understood the violence exerted on ancient forms of life-especially the humbler ones-and communal organisation, and the effects on the partial independence of rural masses with respect to wage labour and the market. ${ }^{107}$ The impact on the social structure of the nation would be extremely profound and irreversible. For some this change was in the 'general interest', others believed it was the prelude to disaster: '[m]odern policy is, indeed, more favourable to the higher classes of people; and the

\footnotetext{
97 Griffin, More-than-human histories and the failure of grand state schemes (note 82), 451.

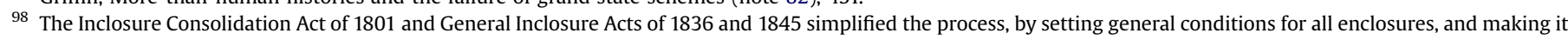
unnecessary to draft individual laws.

99 Blum, English parliamentary enclosure (note 2), 484-485, 492.

100 Hammond and Hammond, The Village Labourer, 1760-1832 (note 67), 63-64.

101 Hammond and Hammond, The Village Labourer, 1760-1832 (note 67), 58.

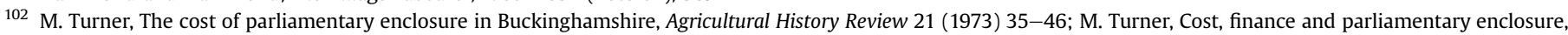
Economic History Review 34 (1981) 236-248, 239.

103 A.H. Johnson, The Disappearance of the Small Landowner, Oxford, 1909, 132-135. See also Dobb, Studies in the Development of Capitalism (note 30), 228.

104 Quoted in Neeson, Commoners (note 58), 15.

105 Neeson, The opponents of enclosure in eighteenth-century Northamptonshire (note 58), 139.

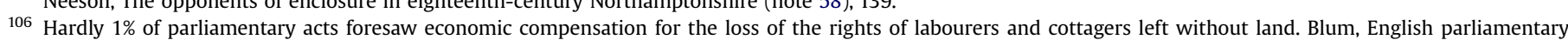
enclosure (note 2), 485.

107 Neeson, Commoners (note 58); Hindle, On the Parish? (note 74), 29.
} 
consequence ... may in time prove, that the whole kingdom will consist of only gentry and beggars, ... grandees and slaves' ${ }^{108}$

But the aftermath was not limited to class struggle-for example, the process had significant repercussions for the household, profoundly altering the role of women at home, and we should also consider, for example, the environmental impact of deforestation and other transformations that followed enclosure. Class dispossession, gender dispossession, dispossession of nature... the process involved even the dispossession of the very capacities of people to respond to these attacks. Naturally, parliamentary enclosure continued to give rise to a series of riots and everyday resistance, prolonging an immemorial tradition of popular struggle. ${ }^{109}$ However, with the dawn of the nineteenth century, the commons became more and more scarce, ancestral forms of right and customs began to wane and die out and the bitterness and collective nature of the resistance subsided. Whereas its characteristic form in the sixteenth century was based on popular revolt and violence, and the threat of 'Cuttynge of throatts' for the lords and their sheep, ${ }^{110}$ in the nineteenth century, with the new modes of subjectification promoted by enclosure, the characteristic figure was increasingly more that of a John Clare, isolated and solitary, who, displaced, bitterly lamented the eclipse of community in his own individual retirement. ${ }^{111}$

Of course, we can still find memorable episodes of contestation and in a new economic scenario the collective struggle adopts different faces-those of Swing, Ludd, and their successors. But we should not forget that above and beyond mere material dispossession, the elimination of local institutions, social capital and community representations achieved through parliamentary enclosure opened up a deep wound in rural popular practices of socialisation and in the very modes of governing territory. It is a revealing fact that in the nineteenth century a new generation of resistances took the protest to other social arenas, responding to different motivations; moreover, it was channelled through routes as normalised and far removed from the spaces of rural everyday life as parliamentary enclosure itself. I am here referring to the campaigns of institutions such as the Commons Preservation Society-led by John Stuart Mill amongst others ${ }^{112}$-and its legal actions and initiatives against the predation of urban commons for the purposes of construction. This experience is comparable to the contemporary Park Movement and other initiatives for urban reform which flourish as an antidote against the proliferation of contradictions in the industrial city.

It is precisely this welfarist genealogical thread that has been traced and narrated by conventional planning history in all-too familiar forms. ${ }^{13}$ Foucauldian accounts of the role of techniques in the evolution of rationalities of power and the logic of social ordering should help us to not only enrich conventional views on history and territory, but also to disassemble them and show their mystifications and internal contradictions. ${ }^{114}$ In this article, consideration of the process of formation of new territorial technologies and their articulation with the emergence of wider historical governmentalities has led to other geographies and other codes habitually ignored by planning history. For parliamentary enclosure already spoke the language of planning. It produced new territories and channelled new territorialities through a complex, conscious strategy which attempted to use space as an instrument of mediation in the forms of subaltern social reproduction. It was a strategy targeted by a specific political subject and subordinated to a project for constructing a hegemonic new social order. Furthermore, it was developed through a series of regulated, normalised legal mechanisms, specifically designed to attenuate contestation-and thus impregnated by a governmental reasonunder the protection and intervention of public institutions-the state, local or regional governments and juridical and technical authorities. In addition to the enclosed fields and the disappearance of ancient forms of life and common self-government, its products were agricultural day-labourers and domestic workers totally dependent on a wage, those abandoned figures whom Marx referred to in the Grundrisse as nackte Individuen, naked individuals, essential pieces in the social structure of the emerging capitalist order.

\section{Acknowledgements}

I wish to thank Simon Gunn, Director of the Centre for Urban History - University of Leicester, and three anonymous referees for their kind advice and comments on earlier versions of this paper.

\footnotetext{
108 Price, Observations on Reversionary Payments (note 1), 158 (emphases in original).

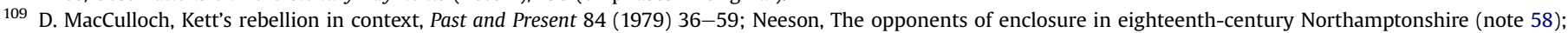
Walter, A 'rising of the people'? (note 59).

110 R. Wilson, 'Like the old Robin Hood': 'As you like it' and the enclosure riots, Shakespeare Quarterly 43 (1992) 1-19, 3.

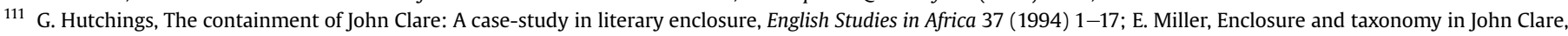
Studies in English Literature, 1500-1900 40 (2000) 635-657.

112 B. Cowell, The Commons Preservation Society and the campaign for Berkhamsted Common, Rural History 13 (2002) $145-161$.

113 Huxley, Problematizing planning (note 4).

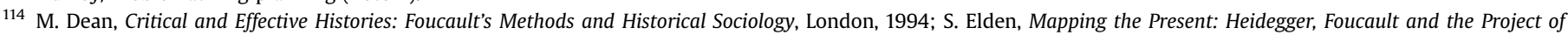
a Spatial History, London, 2001.
} 